\title{
Analyzing The Potential Bankruptcy of Sharia Life Insurance Companies In Indonesia
}

\author{
Rosalendro Eddy Nugroho, Parwito
}

\begin{abstract}
The research purpose to analyze the potential bankruptcy of sharia life insurance companies in Indonesia using Altman Z-Score, Springate and Zmijewski methods. Moreover, it was conducted to find out the differences of those three methods and determine the accurate method among them. The sampling method used is purposive sampling. The population was 24 sharia life insurances industries and 19 that meet the criteria as sample in the period 2013-2017. This research used three approaches of bankruptcy method, called Altman Z-Score, Springate and Zmijewski and next the comparison test. The results of potential bankruptcy showed that the Altman predicted $4 \%$ of sharia life insurances went bankrupt, $7 \%$ were in a vulnerable category and $89 \%$ were in the healthy category. The Springate predicted the companies went bankrupt was $9 \%$ and $91 \%$ of companies were in the healthy category. However, Zmijewski's predicted that no companies potentially bankruptcy, in other words all companies were in healthy category. The results of comparison test showed that there were significant differences between Altman and Springate method, Altmand and Zmijewski method, and Springate and Zmijewski method. At last, the most accurate method in predicting sharia life insurance companies was Springate method with $9 \%$ accuracy.
\end{abstract}

Index Terms-bankruptcy method, Altman Z-Score, Springate, Zmijewski

\section{INTRODUCTION}

In the middle of sharia insurance industries development, a number of sharia insurance companies experiencing bankruptcy such as PT. Asuransi Syariah Mubarakah, PT. Asuransi Tafakul Umum, PT. Asuransi Bumi Asih Jaya, and PT. Asuransi Bumi Putera 1912. Based on that condition, it's important for sharia insurance companies to analyze the potential bankruptcy continuously. In order to know in advance whether the companies will experience bankruptcy or not, they take some preventive steps so that there is no bankruptcy in the future. There are three methods in predicting potential bankruptcy of companies, namely Zmijewski, Altman, and Springate method.

The objectives of this research are: 1) To predict sharia insurance companies which condition are bankrupt or not using three approaches, namely Zmijewski, Altman, and Springate method. 2) To find out the significant differences among Zmijewski, Altman, and Springate method as bankruptcy prediction. 3) To compare those three methods in finding which the most accurate method of all.

Parwito , Master of Management Program, Universitas Mercu Buana, Jakarta, Indonesia

Rosalendro Eddy Nugroho, Master of Management Program, Universitas Mercu Buana, Jakarta, Indonesia

\section{LITERATUR REVIEW}

According to Hanafi (2013:82), explaining the definition of bankruptcy can be seen from cash flow and stock approaches. By using stock approach, a company will go bankrupt if the total liabilities exceed the total assets. Otherwise, based on cash flow approach, a company will go bankrupt when it cannot generate sufficient cash flow. From the point of view of the stock, the company can be declared bankrupt although it may still generate sufficient cash flow, or have good prospects in the future. Hanafi and Halim (2012:79) also mentioned that the problem can lead bankruptcy is short-term financial difficulties which imply to non-solvable difficulties. That is companies have difficulties in repaying their debt due to limited assets. The non-solvable difficulties cause liquidation and reorganization for the companies. Bankruptcy prediction in this research uses three methods namely, Altman Z-Score, Springate, and Zmijewski methods.

\section{a. Altman Z-Score Method}

Burhanuddin (2015:75) explained the pioneer of bankruptcy methods is Beaver (1966), continued by Edward Altman with his research is about financial distress. As Beaver's suggestion, at the end of his writing, Altman made multivariate analysis. This kind of method becomes the most popular method in predicting financial distress which is known as Z-Score Method. Altman's research uses step-wise multivariate discriminant analysis method. Since this research takes sharia insurance companies as non-manufacturing companies, so the formula used is a ratio of four, as followed:

Z-Score $=6,56 \mathrm{X} 1+3,26 \mathrm{X}_{2}+6,72 \mathrm{X}_{3}+1,05 \mathrm{X}_{4}$, Altman (2015:6)

Remarks:

$\mathrm{X}_{1}=$ Working capital/total assets

$\mathrm{X}_{2}=$ Retained earnings/total assets

$\mathrm{X}_{3}=$ Earnings before interest and taxes/total assets

$\mathrm{X}_{4}=$ Market value of equity/book value of total debt

According to Altman, the criteria of bankruptcy are:

$\mathrm{Zi}>2,90$ : classified as healthy companies

$\mathrm{Zi}>1,20$ : classified as bankrupt companies

Zi 1,20 - 2,90: classified as vulnerable bankrupt, which cannot be said as potentially bankrupt or healthy companies ( Hanafi and Halim, 2012:274)

\section{b. Springate Method}

Burhanuddin (2010:82) stated that Springate developed this kind of prediction method in 1978. In its development, Springate used the same method of Altman, namely Multiple Discriminant Analysis. Firstly, Springate (1978) collected 
popular financial ratios which can be used to predict financial distress. The initial ratio was 19 ratios, then after going through the same test as done by Altman (1968), Springate chooses 4 ratios which were believed to be able to distinguish between distress or non-distress companies. Springate took 40 companies in Canada as samples in his research. Those Springate's method (1978) is:

$\mathrm{S}=1,03 \mathrm{~A}+3,07 \mathrm{~B}+0,66 \mathrm{C}+0,4 \mathrm{D}$ ( Peter and Yoseph, 2011:4)

\section{Remarks:}

1. Working capital/total assets (A)

2. Earnings before interest and taxes/total assets (B)

3. Profit before tax/current liabilities (C)

4. Sales/total assets (D)

Criteria:

Cut off that applies in this method is 0,862 . If the company has value less than 0,862 the company classified as potential company bankrupt. Meanwhile, if the value is more than 0,862 the company classified as healthy company.

\section{c. Zmijewski Method}

Zmijewski (1983) used analysis of liquidity ratio, leverage, measurement of company's performance in his prediction method. In analyzing his prediction, Zmijewski took 75 bankrupt companies and 73 healthy companies along 1972 to 1978 . F-Test indicator on the ratio of the rate of return, liquidity, leverage turnover, fixed payment coverage, trends, firm size, and stock return volatility, show a significant difference between healthy and potentially bankrupt companies.

This kind of model produces formula as follows:

$\mathrm{Z}=-4,3-4,5 \mathrm{X}_{1}+5,7 \mathrm{X}_{2}-0,004 \mathrm{X}_{3}$, (Peter and Yoseph, 2011:4)

Remarks:

1. Profit after tax/ total assets $\left(\mathrm{X}_{1}\right)$

2. Total Debt/ total assets $\left(\mathrm{X}_{2}\right)$

3. Current assets/ current liabilities $\left(\mathrm{X}_{3}\right)$

Criteria:

If the score obtained is more than 0 (zero), the company is predicted to go bankrupt, but if the score obtained is less than 0 (zero), the company is predicted not to have potential bankruptcy.

\section{d. Framework}

Framework in this research:

1) Explains that each method calculates to obtain their values, then comparing these values based on their respective criteria according to their methods.

2) Performing Average Difference Test among these three methods (Altman Z-Score, Springate, and Zmijewski Methods)

3) Determining which is the most accurate method to predict the bankruptcy of the companies.

\section{METHOD}

\section{Type of Research}

Sugiyono (2014:75) stated that this research methodology is a scientific way used to obtain objective, valid, and reliable data of being able to be discovered, developed, and proven a certain knowledge so that can be used to understand, solve, and anticipate problems. It is descriptive method used in this research which aims to describe the characteristic of situation or object of the research. This research begins with data collection, quantitative data analysis, and statistical testing (Sugiyono, 2014:207)

\section{Operational Variable Definition}

Research variables are things that shape what is defined by the researchers to be studied in order to obtain information about it (Sugiyono 2014:57)

Tabel 1. Variable Operational Definition

\begin{tabular}{|c|c|c|}
\hline Variable & Method & Scale \\
\hline Altman Z-Score & $\mathrm{X}_{1}=$ Working capital/total assets & Ratio \\
\hline Method & $\mathrm{X}_{2}=$ Retained earnings/total assets & \\
\hline \multirow{2}{*}{$\begin{array}{l}\text { (Altman, } \\
\text { 2015:6) }\end{array}$} & $\begin{array}{l}\mathrm{X}_{3}=\text { Earnings before interest and } \\
\text { taxes/total assets }\end{array}$ & \\
\hline & $\begin{array}{c}\mathrm{X}_{4}=\text { Market value of equity/book } \\
\text { value of debt }\end{array}$ & \\
\hline Springate & $\mathrm{A}=\mathrm{W}$ orking capital/total assets & \multirow[t]{5}{*}{ Ratio } \\
\hline Method & $\begin{aligned} \mathrm{B}= & \text { Earnings before interest and } \\
& \text { taxes/total assets }\end{aligned}$ & \\
\hline (Peter and & $\mathrm{C}=$ Profit before tax/current & \\
\hline \multirow[t]{2}{*}{ Yosep, 2011:5) } & liabilities & \\
\hline & $\mathrm{D}=$ Sales/total assets & \\
\hline Zmijewski & $\mathrm{X}_{1}=$ Profit after tax/total assets & \multirow[t]{3}{*}{ Ratio } \\
\hline Method & $\mathrm{X}_{2}=$ Total debt/total assets & \\
\hline $\begin{array}{l}\text { (Peter and } \\
\text { Yosep, 2011:7) }\end{array}$ & $\mathrm{X}_{3}=$ Current assets/current liabilities & \\
\hline
\end{tabular}

Total population used in this research is 24 sharia life insurance listed on Indonesia Stock Exchange in period 2014-2017. The sampling method used is purposive sampling. In addition, 19 companies that meet the sample criteria.

Tabel 2. The Criteria of Sample

\begin{tabular}{llc}
\hline No & \multicolumn{1}{c}{ Criteria } & $\begin{array}{c}\text { Total } \\
\text { Data }\end{array}$ \\
\hline 1 & Sharia life insurance companies & 24 \\
2 & $\begin{array}{l}\text { Company with incomplete financial } \\
\text { statements during the 2013-2017 periods. }\end{array}$ & $(5)$ \\
Total Sampel & 19 \\
Time of reseacrh 2013-2017 & \\
Total data & $\mathbf{9 5}$ \\
\hline
\end{tabular}

\section{Data Analysis Method}

a. Bankruptcy Method

Calculation Methods used in this research are: 1) Altman Z-Score Method, 2) Springate Method, 3) Zmijewski Method

\section{b. Descriptive Analysis}

Descriptive analysis will provide an overview of data distribution. In a research, descriptive analysis also provides an overview of the data as seen from the average value, standard deviation, maximum, and minimum.

c. Comparative Test 
International Journal of New Technology and Research (IJNTR)

ISSN: 2454-4116, Volume-4, Issue-10, October 2018 Pages 54-61

Difference test or comparative tes using Independent sample $t$ Test is a test used to determine whether two unrelated samples have different average (Nugroho, 2016:49) The comparative $t$ Test is done by comparing the differences between two average values with the standard error of the average difference between two samples

\section{RESULT AND DISCUSSION}

There were 19 sharia life insurance companies in Indonesia used in this research for 2013-2017 periods. They consist of full-life sharia insurance companies and sharia units. This research used secondary data taken from those companies' financial statement.

\section{a. Bankruptcy Method}

\section{Altman Z-Score Method}

Based on Altman Z-Score prediction, total data was 95 companies data where 84 companies were healthy, 4 companies have value $\mathrm{Z}$-score $<1,20$ were classified as bankrupt, and 7 companies have Z-Score 1,20 - 2,90 were classified as vulnerable to bankruptcy. According to Altman Z-Score prediction, there are 2 companies were classified as bankrupt companies. They are PT. Al-Amin Life insurance (bankrupt in 2014, 2015, and 2017) and PT. Sun Life Financial Indonesia (bankrupt in 2016).

\begin{tabular}{|l|}
\hline \multicolumn{1}{|c|}{ Altman Z-Score Methode } \\
Measurements used: \\
$\mathrm{X}_{1}$ (Working capital to total assets) \\
$\mathrm{X}_{2}$ (Retained earnings to total assets) \\
$\mathrm{X}_{3}$ (Earnings before interest and taxes to total assets) \\
$\mathrm{X}_{4}$ (Market value of equity to book value) \\
$\mathrm{Z}$-Score $=6,56 \mathrm{X}_{1}+3,62 \mathrm{X}_{2}+6,72 \mathrm{X} 3+1,05 \mathrm{X}_{4}$ \\
\hline
\end{tabular}

\section{Score Criteria of Altman Z-Score Method}

AZ-Score $>2,90$ classified as healthy companies

AZ-Score $<1,20$ classified as bankrupt companies

AZ-Score 1,20 - 2,90 classified as companies are vulnerable to bankruptcv

\section{Category:}

The Calculation Result of Altman Z-Score

$1.4(4 \%)$ companies were classified as bankrupt companies

PT. Al-Amin Life insurance (bankrupt in 2014, 2015, and 2017) and PT. Sun Life Financial Indonesia (2016).

2. $84(89 \%)$ companies were healthy

$3.7(7 \%)$ comnanies were classified as vulnerable to

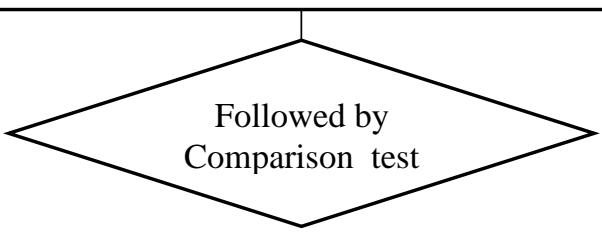

Picture 1. Altman Z-Score Calculation Results

Source: Data processed in 2018

2. Springate Method
Springate method stated that 86 companies experienced a healthy period from total 95 companies, and 9 companies were predicted to bankrupt. In this method, if the score $<0,862$ indicates that the company will go bankrupt. They are PT Amanah Githa (in 2013, 2014 and 2015), PT Tokio Marine Life Insurance Indonesia (in 2013, 2015 and 2016), and PT Al-Amin Life Insurance (in 2014, 2015 and 2017).

Springate Methode
Measurements used:
A = Working capital to total assets
$\mathrm{B}=$ Earnings before interest and taxes to total assets
$\mathrm{C}=$ Profit before tax to current liabilities
$\mathrm{D}=$ Sales to total assets
$\mathrm{S}=1,03 \mathrm{~A}+3,07 \mathrm{~B}+0,66 \mathrm{C}+0,4 \mathrm{D}$

Score Criteria of Springate Method

S Score $<0,862$ classified as potential company bankrupt S Score $>0,862$ classified as healthy company

The Calculation Result of Springate Method

\section{Category:}

1. $9(9 \%)$ companies would go bankrupt PT Amanah Githa (in 2013, 2014 and 2015), PT Tokio Marine Life Insurance Indonesia (in 2013, 2015 and 2016), and PT Al-Amin Life Insurance (in 2014, 2015 and 2017).

2. $86(91 \%)$ companies were healthy companies

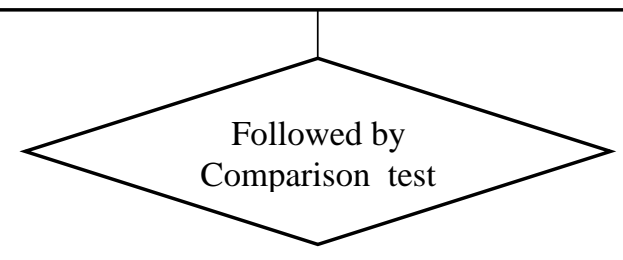

Picture 2. Springate Calculation Results Source: Data processed in 2018

\section{Zmijewski Method}

The calculation result of Zmijewski method used cut-off score. If the score was $>0$ (zero), the companies were predicted to go bankrupt. However, if the score was $<0$ (zero), the companies were classified as healthy companies. Based on Zmijewski prediction along these 5 years, the score of 95 data of insurance companies were under 0 . It means that all companies were classified as healthy companies and no bankruptcy detected. 


\begin{tabular}{|l|}
\hline \multicolumn{1}{|c|}{ Zmijewski Methode } \\
Measurements used: \\
$\mathrm{X}_{1}=$ Profit after tax to total assets \\
$\mathrm{X}_{2}=$ Total debt to total assets \\
$\mathrm{X}_{3}=$ Current assets to current liabilities \\
$\mathrm{Z}=4,3-4,5 \mathrm{X}_{1}+5,7 \mathrm{X}_{2}+0,004 \mathrm{X}_{3}$ \\
\hline
\end{tabular}

\begin{tabular}{|l|}
\hline Score Criteria of Zmijewski Method \\
Z Score $>0$ (zero) potentially bankrupt \\
Z Score $<0$ (zero) in healthy condition \\
\hline
\end{tabular}

The Calculation Result of Zmijewski Method

Category:

1. $0(\%)$ company would go bankrupt

2. $95(100 \%)$ companies were in healthy condition

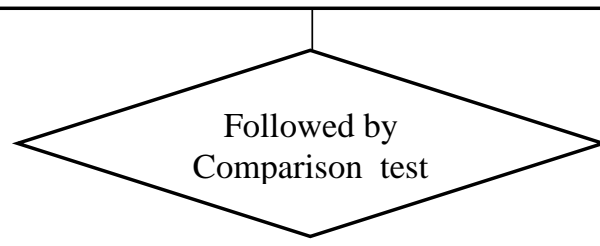

Picture 3. Zmijewski Calculation Results

Source: Data processed in 2018

\section{b. Results of Descriptive Analysis}

\section{Altman Z-Score Descriptive Analysis}

The mean value for the Altman Z-Score was 39,02 with std. deviation value was 145,68. In 2017, PT Al Amin Sharia Life Insurance was in the minimum value 1,99 . Meanwhile, PT Bringin Life Insurance reached the maximum value $1.037,81$ in 2013 .

Table 4. Altman Z-Score Descriptive Analysis

\begin{tabular}{|c|c|c|c|c|c|c|}
\hline No & Name & $\begin{array}{c}\mathrm{X}_{1} \\
\text { Current } \\
\text { assets/ } \\
\text { total } \\
\text { assets }\end{array}$ & $\begin{array}{c}\mathrm{X}_{2} \\
\text { Retained } \\
\text { earnings/ } \\
\text { total } \\
\text { assets }\end{array}$ & $\begin{array}{c}\mathrm{X}_{3} \\
\text { Earnings } \\
\text { before } \\
\text { interest } \\
\text { and taxes } \\
\text { /total } \\
\text { assets } \\
\end{array}$ & \begin{tabular}{l}
\multicolumn{1}{c}{$\mathrm{X}_{4}$} \\
Market \\
value of \\
common \\
/book \\
value
\end{tabular} & $\begin{array}{c}\text { AZ } \\
\text {-Score }\end{array}$ \\
\hline 1 & Min & $-0,357$ & $-1,561$ & $-0,430$ & 0,248 & $-1,99$ \\
\hline 2 & $\operatorname{Max}$ & 2,469 & 0,742 & 0,579 & 985,860 & $1.037,81$ \\
\hline 3 & Mean & 0,667 & 0,141 & 0,077 & 32,063 & 39,02 \\
\hline 4 & $\begin{array}{c}\text { Std. } \\
\text { Deviation }\end{array}$ & 0,408 & 0,457 & 0,159 & 138,672 & 145,68 \\
\hline
\end{tabular}

Source: Data processed in 2018

\section{Springate Descriptive Analysis}

Based on this descriptive analysis, PT Tokio Marine Life Insurance had minimum springate value in 2013 with a value of $-16,68$. Moreover, the maximum value was 172,43 obtained by PT Bringin Life Insurance in 2013. It means that the mean value was 9,15 and std. deviaton was 17,77 .
Tabel 5. Springate Descriptive Analysis

\begin{tabular}{ccccccc}
\hline No & Name & $\begin{array}{c}\text { A } \\
\text { Working } \\
\text { capital } \\
\text { /total } \\
\text { assets }\end{array}$ & $\begin{array}{c}\text { B } \\
\text { Earnings } \\
\text { before } \\
\text { interest and } \\
\text { taxes/total } \\
\text { assets }\end{array}$ & $\begin{array}{c}\text { C } \\
\text { Profit } \\
\text { before } \\
\text { tax/current } \\
\text { liabilities }\end{array}$ & $\begin{array}{c}\text { D } \\
\text { Sales/ } \\
\text { total } \\
\text { assets }\end{array}$ & S-Score \\
\hline 1 & Min & $-0,357$ & $-0,430$ & $-38,595$ & 0,041 & $-16,68$ \\
2 & Max & 2,469 & 0,579 & 254,500 & 0,909 & 172,43 \\
3 & Mean & 0,667 & 0,077 & 4,363 & 0,240 & 9,15 \\
4 & $\begin{array}{c}\text { Std. } \\
\text { Deviation }\end{array}$ & 0,408 & 0,159 & 26,831 & 0,214 & 17,77 \\
\hline
\end{tabular}

Source: Data processed in 2018

\section{Zmijewski Descriptive Analysis}

It stated that PT Bringin Life Insurance (BRI Life) had minimum value or the highest score with its value was $-74,32$ in 2013 and the maximum value was obtained by PT Central Asia Raya Life Insurance with the value was -0,03 in 2017. Overall, the mean value was $-4,14$ with std deviation 7,40 .

Tabel 6. Zmijewski Descriptive Analysis

\begin{tabular}{|c|c|c|c|c|c|}
\hline \multirow[t]{2}{*}{ No } & \multirow[t]{2}{*}{ Name } & $\mathrm{X}_{1}$ & \multirow{2}{*}{$\begin{array}{c}\mathrm{X}_{2} \\
\text { Total } \\
\text { debt/total } \\
\text { assets }\end{array}$} & \multicolumn{2}{|l|}{$\mathrm{X}_{3}$} \\
\hline & & $\begin{array}{c}\text { Profit after } \\
\text { tax/total assets }\end{array}$ & & $\begin{array}{l}\text { Current } \\
\text { assets/current } \\
\text { liabilities }\end{array}$ & Z-Score \\
\hline 1 & Min & $-0,466$ & 0,0004 & 0,368 & $-74,32$ \\
\hline 2 & $\operatorname{Max}$ & 0,579 & 0,654 & $17.498,000$ & $-0,03$ \\
\hline 3 & Mean & 0,071 & 0,242 & 224,372 & $-4,14$ \\
\hline 4 & $\begin{array}{c}\text { Std. } \\
\text { Deviation }\end{array}$ & 0,151 & 0,170 & $1.792,772$ & 7,40 \\
\hline
\end{tabular}

Source: Data processed in 2018

\section{c. Correlation Analysis}

\section{Altman Z-Score and Springate Methods}

Based on result analysis represented by table 7 of Levene's Test for Equality of Variances, the result of F test 12,957 with a significance value of 0,000 (probability < $0,05)$. Since the probability number $<0,05$ so $\mathrm{H} 1$ is accepted and Ho is rejected. It means, there is a variant difference between Altman Z-Score and Springate methods.

That variance test shows that both of those methods have difference in their variances. Hence, the use of variance to compare the average bankruptcy method (t-test for Equality of Means) in the t-test with the basis of equal variance is not assumed. At equal variance not assumed $t$ value is 1,986 with a probability level of 0,050 . The results show that $(0,050<0,050)$, probability or significance $<0,05$, $\mathrm{H} 0$ is rejected which means that there are significant differences between Altman Z-Score and Springate methods. 
International Journal of New Technology and Research (IJNTR)

ISSN: 2454-4116, Volume-4, Issue-10, October 2018 Pages 54-61

Tabel 7. Independent Samples Test Altman Z-Score and Springate Methods Independent Samples Test

\begin{tabular}{|c|c|c|c|c|c|c|c|c|c|c|}
\hline & & \multicolumn{2}{|c|}{$\begin{array}{c}\text { Levene's Test for } \\
\text { Equality of } \\
\text { Variances }\end{array}$} & \multicolumn{7}{|c|}{ t-test for Equality of Means } \\
\hline & & \multirow[t]{2}{*}{$F$} & \multirow[t]{2}{*}{ Sig. } & \multirow[t]{2}{*}{$t$} & \multirow[t]{2}{*}{$d f$} & \multirow[t]{2}{*}{$\begin{array}{c}\text { Sig. } \\
\text { (2-tailed) }\end{array}$} & \multirow[t]{2}{*}{$\begin{array}{c}\text { Mean } \\
\text { Difference }\end{array}$} & \multirow[t]{2}{*}{$\begin{array}{l}\text { Std. Error } \\
\text { Difference }\end{array}$} & \multicolumn{2}{|c|}{$\begin{array}{c}95 \% \text { Confidence } \\
\text { Interval of the } \\
\text { Difference }\end{array}$} \\
\hline & & & & & & & & & Lower & Upper \\
\hline \multirow{2}{*}{ Metode } & $\begin{array}{l}\text { Equal variances } \\
\text { assumed }\end{array}$ & 12,957 &, 000 & 1,986 & 188 &, 048 & 29,902 & 15,056 & ,202 & 59,602 \\
\hline & $\begin{array}{l}\text { Equal variances } \\
\text { not assumed }\end{array}$ & & & 1,986 & 96,798 &, 050 & 29,902 & 15,056 & ,019 & 59,784 \\
\hline
\end{tabular}

Data processed in 2018

\section{Altman Z-Score and Zmijewski Methods}

As shown on Table 8 below, Levene's Test for Equality of Variances have the results of $F$ test 15,293 and a probability value of 0,000 or $(0,000<0,05)$. Since the probability number $<0,05$ so $\mathrm{H} 1$ is accepted and $\mathrm{HO}$ is rejected. It means that there is variant difference between Altman Z-Score and Zmijewski Methods.
The results of bankruptcy test shows that they have difference in their variances, so the use of variance to compare the average bankruptcy method (t-test for Equality of Means) in the t-test is the basis of equal variance is not assumed. At the results of equal variance not assumed, the researchers get $t$ value is 2,886 with a significance level or probability of 0,050 . The results show that $(0,050<0,050)$, probability or significance $<0,05, \mathrm{H} 0$ is rejected which means that there are significant differences between Altman Z-Score and Zmijewski methods.

Tabel 8. Independent Samples Test Altman Z-Score and Zmijewski Independent Samples Test

\begin{tabular}{|c|c|c|c|c|c|c|c|c|c|c|}
\hline & & \multicolumn{2}{|c|}{$\begin{array}{c}\text { Levene's Test for } \\
\text { Equality of } \\
\text { Variances } \\
\end{array}$} & \multicolumn{7}{|c|}{ t-test for Equality of Means } \\
\hline & & \multirow[t]{2}{*}{$F$} & \multirow[t]{2}{*}{ Sig. } & \multirow[t]{2}{*}{$\bar{t}$} & \multirow[t]{2}{*}{$d f$} & \multirow[t]{2}{*}{$\begin{array}{c}\text { Sig. } \\
\text { (2-tailed) }\end{array}$} & \multirow[t]{2}{*}{$\begin{array}{c}\text { Mean } \\
\text { Difference }\end{array}$} & \multirow[t]{2}{*}{$\begin{array}{l}\text { Std. Error } \\
\text { Difference }\end{array}$} & \multicolumn{2}{|c|}{$\begin{array}{c}95 \% \text { Confidence Interval of } \\
\text { the Difference }\end{array}$} \\
\hline & & & & & & & & & Lower & Upper \\
\hline \multirow{2}{*}{$\begin{array}{l}\text { Metode } \\
\text { A-Z }\end{array}$} & $\begin{array}{l}\text { Equal variances } \\
\text { assumed }\end{array}$ & 15,293 & ,000 & 2,886 & 188 & ,004 & 43,188 & 14,964 & 13,669 & 72,708 \\
\hline & $\begin{array}{l}\text { Equal variances } \\
\text { not assumed }\end{array}$ & & & 2,886 & 94,485 &, 005 & 43,188 & 14,964 & 13,478 & 72,898 \\
\hline
\end{tabular}

Source: Data processed in 2018

\section{Springate and Zmijewski Methods}

From Table 9, it can be seen that Levene's Test for Equality of Variances produces the results of $F$ test 4,548 and a probability value of 0,034 or $(0,034<0,05)$. The results of the analysis shows that the probability number $<0,05$, so $\mathrm{H} 1$ is accepted and $\mathrm{H} 0$ is rejected. It means that there is variant difference between Springate and Zmijewski Methods.

Since there is difference variance found between Springate and Zmijewski Method, so the use of variance to compare the average bankruptcy method (t-test for Equality of Means) in the t-test is the basis of equal variance is not assumed. At the results of equal variance not assumed, the researchers get $t$ value is 128,646 with a significance level or probability of 0,050 . The results show that $(0,050 \leq 0,050)$, probability or significance $<0,05, \mathrm{H} 0$ is rejected which means that there are significant differences between Springate and Zmijewski methods.

Tabel 9. Independent Samples Test Springate and Zmijewski

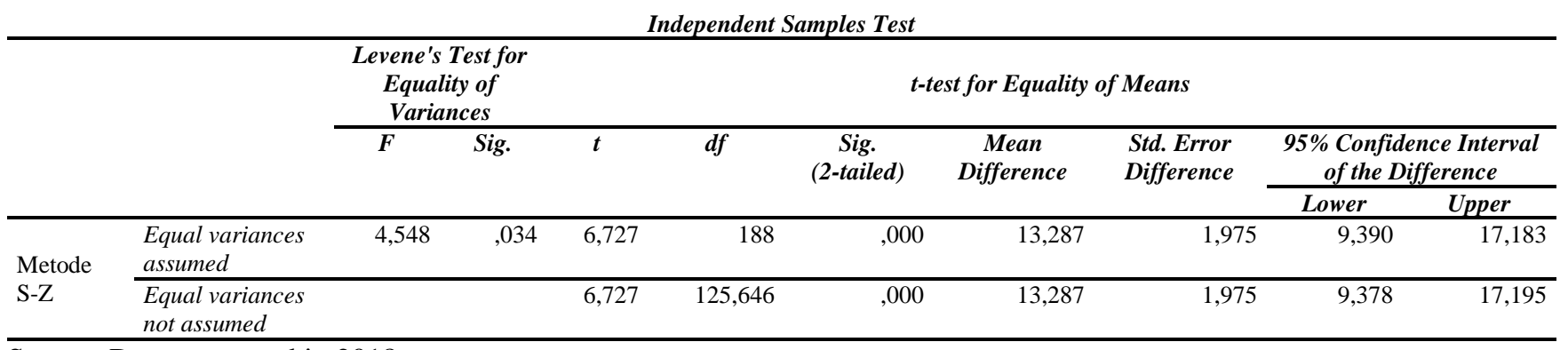

Source: Data processed in 2018

\section{Comparison of Bankruptcy Method Results}

The comparison results from the three methods show that there is a difference in accuracy between the results of bankruptcy analysis with Altman Z-Score, Springate, and Zmijewski model. From this research, the researchers found the results:Altman Z-Score with 4\%, Springate 9\%, and 
Zmijewski 0\% accuracy. Thus, it can be concluded that the most accurate bankruptcy method to predict sharia life insurance in Indonesia is Sringate method with an accuracy of $9 \%$.

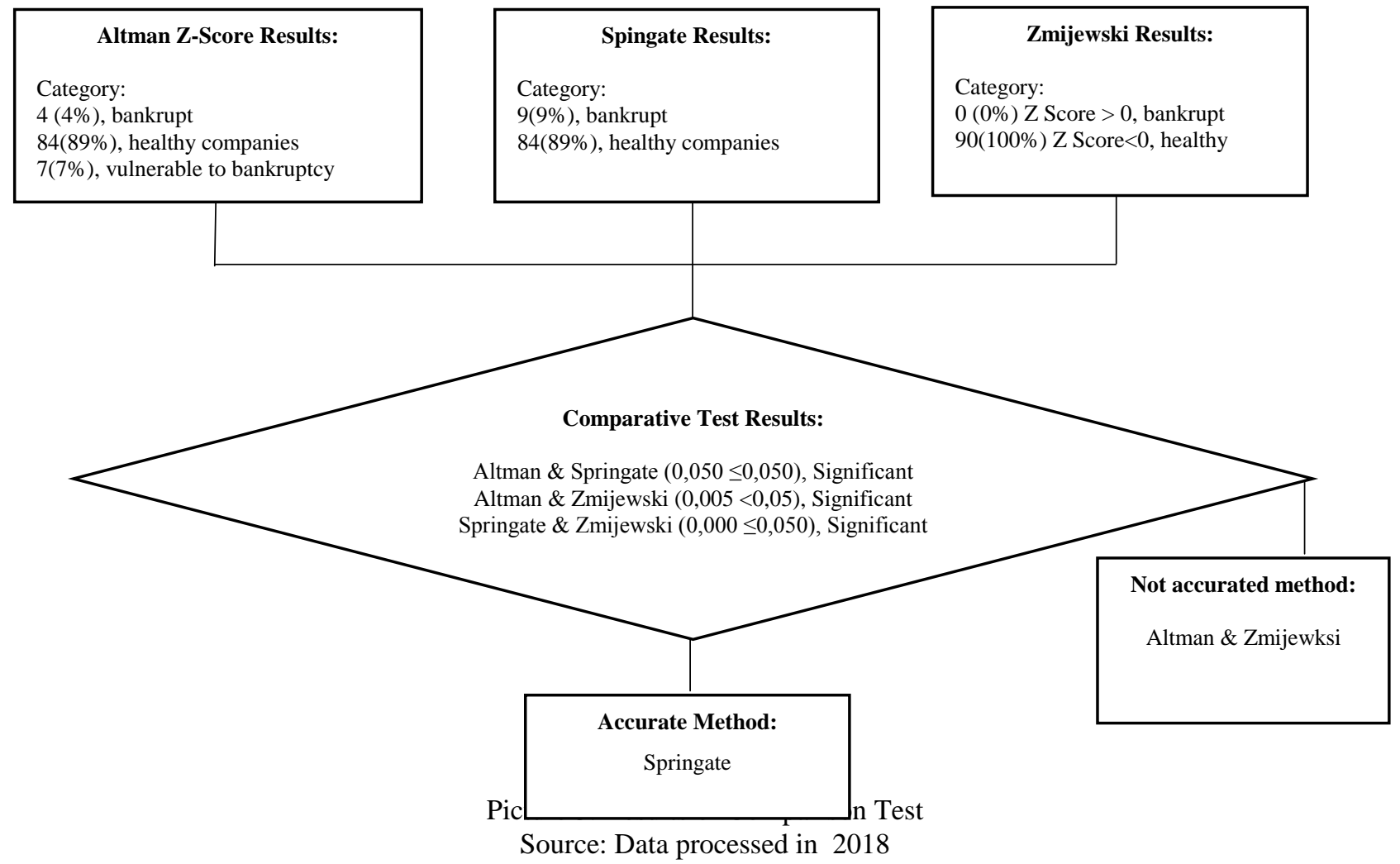

\section{Discussion}

\section{Altman Z-Score Method}

Altman bankruptcy method predicted, 84 (89\%) companies were healthy, 4 (4\%) companies were detected bankrupt, and 7 (7\%) companies were classified as vulnerable to bankruptcy. The result of difference test between Altman Z-Score and Springate was obtained a probability $<0.00$ $(0,050 \leq 0,050)$, which means there was significance differences of bankruptcy between them. Moreover, the difference test between Altman Z-Score and Zmijewski showed $(0,005 \leq 0,050)$ with probability value $<0,05$. It means that there was a significant difference of bankruptcy between Altman Z-Score and Zmijewski.

This research supported by Massimiliano's finding result in 2015 where he found Altman Z-Score Method worked effectively in predicting the failures of Italian companies, provided that there are several things that must be taken into account. Another researcher, Mohammed (2017) revealed SAOG Raysut Cement Company and its subsidiaries were financially safe because their Altman Z-Score was higher than the benchmark $(2,99)$, except in few years of study. Begley (2016), the next researcher, showed Ohlson's original model performance was more accurate than Altman, which was often used in academic researches as an indicator to predict bankruptcy.

\section{Springate Method}

Using financial ratios, Springate (S-Score) bankruptcy method concluded that from total 95 data, there were 86 $(91 \%)$ companies were in a healthy condition and $9(9 \%)$ companies were predicted bankrupt. As mentioned in the previous page, there was significant difference of bankruptcy between Springate and Altman Z-Score methods. In addition, the result showed the probability $<0,05$ which means there was also significant difference of bankruptcy between Springate and Zmijewski.

Rahayu (2016) stated that Springate calculation result showed the companies were categorized into financial distress condition. Meanwhile, the analysis results of Yulistary and Wirakusuma (2014) in PT Fast Food Indonesia Tbk using Altman Z-Score, Springate, and Zmijewski Methods showed that it was a healthy company (2008 - 2012). Peter and Yoseph (2011) added, PT Fast Food Indonesia Tbk was classified to not potentially company bankrupt (2005-2009) based on the result of Altman Z-Score, Springate, and Zmijewski prediction.

\section{Zmijewski Method}

Based on Zmijewski prediction along these 5 years, it concluded that 95 data insurance companies had $\mathrm{S}<0$. It means that all companies were classified as healthy companies and no bankruptcy detected. Probability of difference test result between Zmijewski and Altman Z-Score was $<0,05$, which means there is a significant difference between them. Moreover, Zmijewski and Springate's difference test showed a probability of $<0.05$, which means there was a significant difference between Springate and the Zmijewski bankruptcy method.

According to Muhammad and Nunung (2016), there were significant differences between the Altman Z-score model, the Springate S-Score and the Zmijewski X-Score in assessing bankruptcy in property industry companies. Besides, Tri and Arlin (2014) used Altman and Springate Methods to predict bankruptcy in mining and oil-gas sub-sector companies. They are ELSA company in 2009 and RUIS 
company in 2010. Both of them were classified to healthy companies.

\section{Accurate Bankruptcy Methods}

From the comparison of three bankruptcy methods, Altman, Springate dan Zmijewski, the researchers obtained the results: Altman with $4 \%$ accuracy, Springate with $9 \%$ accuracy, and Zmijewski with $0 \%$ accuracy. So, it can be concluded that the most accurate bankruptcy method to predict sharia life insurance companies in Indonesia is Springate method with $9 \%$ accucary.

This conclusion is supported by Diyah and Agung (2017), stating that the most appropriate method to predict Islamic bank in Indonesia is Springate method with 38,00\% accuracy, then Zmijewski with $28,00 \%$ accuracy and Altman with $0,00 \%$ accuracy. Then, Sari (2014) stated that Springate is the most appropriate method for transportation companies in Indonesia, because its accuracy is high at $33,33 \%$. Prihantini (2013) stated that Altman had same accuracy result as Springate. In the other hand, Maria (2013) declared that Grover Method has the highest accuracy compared to other prediction methods with $100 \%$ accuracy, followed by Springate with $90 \%$ accuracy, Zmijewski with $90 \%$ accuracy, and Altman Z-Score with $80 \%$ accuracy.

However, Alkhatib (2011) stated that Altman is much better in predicting company bankrupt with an average prediction capability of $93.8 \%$ from five years before liquidation, while the average Kida method was $69 \%$.

\section{IV.CONCLUSION}

Based on the analysis and discussion in the previous chapters, we can conclude as follow:

1. According to the calculation of bankruptcy methods, Altman method predicted $4 \%$ sharia life insurance companies were bankrupt, $7 \%$ were vulnerable to bankruptcy, and $89 \%$ were healthy. Then, Springate Method predicted only $9 \%$ of sharia life insurance companies were bankrupt and $91 \%$ companies were healthy. Last, Zmijewski Method predicted 0\% company was bankrupt which means all companies were healthy.

2. The difference tests show there was significant difference between Altman and Springate method, Altman and Zmijewski method, and also significant difference between Springate and Zmijewski method.

3. The most accurate bankruptcy method to predict sharia life insurance in Indonesia is Springate method with $9 \%$ accuracy.

Based on the analysis and conclusions above, the researchers suggest as below:

1. Limitations of research information are obtained based on the information contained in the financial report. There is a component of interest rate in the formula used in the bankruptcy method, whereas there is no interest rate in financial report of sharia life insurance.

2. The research is conducted in 2013-2017 period. For next research, it should add length of research period.

3. The researchers used Altman, Springate, and Zmijewski methods in analyzing the data. The next research can add other bankruptcy prediction methods, such as Grover and Fumer.
4. Further research can compare the potential bankruptcy or conduct analysis with other financial ratios. For example, the health assessment of an insurance business that has been established by the Financial Services Authority and Government Regulations, or consider from external factors such as inflation and economic trends.

5. Last, the researchers suggest the management of sharia life insurance companies to make some evaluations and controls to improve companies' performances and anticipate bankruptcy.

\section{REFERENCES}

[1] Abdulkadir, M. (2011). Hukum Asuransi Indonesia. Edisi 5. PT.Citra Aditya Bakti. Bandung.

[2] Alkhatib, Khalid. (2011). Predicting Corporate Bankruptcy of Jordanian Listed Companies: Using Altman and Kida Models. International Journal of Business and Management Vol. 6, No. 3.

[3] Altman, Edward I. (1968). "Financial Ratios, Discriminant Analysis and The Prediction of Corporate Bankruptcy." The Journal of Finance, Vol. XXIII No. 4.

[4] Asuransi Syariah. (2017). Klinik Asuransi. https://klinikasuransi.com/2017/04/04.

[5] Begley, Joy; Jin Ming, Susat Watts. (2006). "Bankruptcy Classification Errors in the 1980s: An Companies: Using Altman and Kida Models." Review of Accounting Studies, 1, 267-284.

[6] Burhanuddin S. (2015). Aspek Hukum Lembaga Keuangan Syari'ah. Graha Ilmu. Yogyakarta.

[7] Burhanuddin. (2010). Analisis Prediksi Kebangkrutan Perusahaan Berdasarkan Model Z-Score Altman Pada Perusahaan Makanan dan Minuman Yang Terdaftar di Bursa Efek Indonesia Periode (2013-2015). Jurnal Ilmiah Akuntansi, Fakultas Ekonomi Universitas Maritim Raja Ali Haji Tanjungpinang, Kepulauan Riau.

[8] Drozdowska, Małgorzata I. Erkki K. Laitinen, and Arto Suvas. (2016). "Distressed Firm and Bankruptcy Prediction in an International Context: A Review and Empirical Analysis of Altman's Z-Score Model." Electronic copy available at http://ssrn.com/abstract=2536340.

[9] Fatwa Dewan Syariah Nasional Majelis Ulama Indonesia No 21/DSN-MUI/X/2001 tentang Pedoman Umum Asuransi Syariah.

[10] Ferbianasari. (2011).Analisis Prediksi Kebangkrutan Pada Perusahaan Farmasi Go Public di Bursa Efek Indonesia dengan Menggunakan Model Altman Z-Score.

[11] Hanafi, M. M. (2013). Manajemen Keuangan. Edisi kesatu. BPFE-Yogyakarta. Yogyakarta.

[12] Hanafi, Mahduh dan Abdul Halim. (2012), Analisis Laporan Keuangan. Yogyakarta: (UPP) STIM YKPN.

[13] Harahap, Sofyan S. (2013). Analisis Kritis Atas Laporan Keuangan Cetakan Kesebelas. Rajawali Pers. Jakarta.

[14] Hawar, Abdulkareem. (2015). The revised Altman Z'-score Model Verifying its Validity as a Predictor of Corporate Failure in the Case of UK Private Companies, Analysis of the Financial Statements contained in Marks and Spencer's Group Plc Annual Reports 2010-2014. Conference Paper. Publication at: https://www.researchgate.net/publication/289673518.

[15] Hayes, Suzanne K. Kay A. Hodge dan Larry W. Hughes. (2010). "A Study of the Efficacy of Altman's Z to Predict Bankruptcy of Specialty Retail Firms Doing Business in Contemporary Times." Economics \& Business Journal: Inquiries \& Perspectives, Vol.3 Nu.1.

[16] Industri Asuransi (2017), https://mediaasuransinews.co.id/2017.

[17] Kepailitan PT Asuransi Jiwa Musyarakah, https://www.konfrontasi.com/content/.

[18] Keputusan Dewan Pimpinan MUI tentang susunan pengurus DSN-MUI, No: Kep-98/MUI/III/2001).

[19] Khalid, Al Rawi; Raj Kiani, dan Rishma R Vedd. (2008). “The Use of Altman Equation for Bankruptcy Prediction in an Industrial Firm (Case Study)" International Business \& Economics Research Journal, Volume 7, No. 7.

[20] Kondisi Keuangan PT AJBB http://katadata.co.id/berita/2016/12/08/kondisi-keuangan-ajb-bumipu tera.

[21] Massimiliano, Celli. (2015). "CAN Z-Score Model Predict Listed Companies' Failures in Italy? An Empirical Test”. International Journal of Business and Management, Vol 10,No. 3. 
[22] Merkevicius, Egidijus; Gintautas Garšva, and Stasys Girdzijauskas. (2006) "A Hybrid SOM-Altman Model for Bankruptcy Prediction." ICCS, Part IV, LNCS 3994, pp. $64-371$.

[23] Miller, Warren. (2009). "Comparing Models of Corporate Bankruptcy Prediction: Distance to Default vs. Z-Score". Available at: http://ssrn.com/abstract=1461704.

[24] Mishkin, Frederic S. (2008). "Ekonomi Uang, Perbankan, dan Pasar Keuangan.” Edisi 8. Salemba Empat. Jakarta.

[25] Mohammed, Shariq. (2017). "Bankruptcy Prediction by Using the Altman Zscore Model in Oman: A Case Study of Raysut Cement Company SAOG and Its Subsidiaries" Australasian Accounting, Business and Finance Journal, Volume 10 No. 4.

[26] Muhammad, T. Abadi dan Nunung Ghoniyah. (2016). Studi Potensi Kebangkrutan Pada Perusahaan Industri Properti Yang Go Public Di Bursa Efek Indonesia. Jurnal Riset Bisnis Indonesia, Vol.13 No.1 Hal 91-100.

[27] Muminović, S. (2013). "Revaluation and Altman`s Z-score-the Case of the Serbian Capital Market". International Journal of Finance and Accounting, 2(1): 13-18.

[28] Ramadhani, Ayu Suci dan Niki Lukviarman. (2009). Perbandingan Analisis Prediksi Kebangkrutan Menggunakan Model Altman Pertama, Altman Revisi, Dan Altman Modifikasi dengan Ukuran dan Umur Perusahaan Sebagai Variabel Penjelas (Studi Pada Perusahaan Manufaktur yang Terdaftar di Bursa Efek Indonesia ). Jurnal Siasat Bisnis. Vol.13 No.1.15-28.

[29] Nugroho, R. Eddy. (2016). Pengenalan \& Aplikasi Penelitian Sosial \& Bisnis Menggunakan SPSS. Jakarta:Universitas Mercu Buana.

[30] dan Sutawidjaya, Achmad H. (2016), Pengantar Manajemen Resiko dan Asuransi. Jakarta.

[31] Maskanah, Siti., (2016), Implementasi Produk Asuransi Jiwa Syariah Terhadap Kestabilan Ekonomi Keluarga, Volume 1 No. 2 (Juli-Desember) 2016, Jurnal. Ekonomi dan Bisnis Islam, Tsarwah.

[32] Otoritas Jasa Keuangan (2015), Statistik Perasuransian Indonesia 2015. Direktorat Jenderal Lembaga Keuangan, Departemen Keuangan Republik Indonesia, Jakarta.

[33] Otoritas Jasa Keuangan. (2017) Daftar Perusahaan Asuransi Jiwa, Umum dan Reasurans dengan Prinsip Syariah, http://www.ojk.go.id/id/kanal/.

[34] Peter dan Yoseph. (2011). "Analisis Kebangkrutan Dengan Metode Z-Score Altman, Springate, dan Zmijewski Pada PT Indofood Sukses Makmur Tbk Periode 2005-2009." Jurnal Ilmiah Akuntansi, Nomor 04 Tahun Ke-2 Januari-April 2011. Universitas Kristen Maranatha.

[35] Prihanthini, Ni Made E.D. dan Maria M. R.S. (2013). "Prediksi Kebangkrutan Grover, Altman, Z-Score, Springate, dan Zmijewsk Pada Perusahaan Food and Beverage di Bursa Efek Indonesia." E-Jurnal Akuntansi Universitas Udayana, Vol.5.2:417.

[36] Puspitasari, Nolita. (2015). Analisis Pengaruh Profitabilitas, Solvabilitas dan Reputasi KAP Terhadap Audit Delay Pada Perusahaan yang Terdaftar Di Indeks Saham Syariah Indonesia Tahun 2009-2013. Skripsi. Universitas Islam Negeri Walisongo.

[37] Rahayu, Fitriani, I Wayan S, dan Ni Nyoman Y. (2016). "Analisis Financial Distress Dengan Menggunakan Metode Altman Z-Score, Springate, dan Zmijewski Pada Perusahaan Telekomunikasi." E-Journal Bisma Universitas Pendidikan Ganesha Jurusan Manajemen, Volume 4.

[38] Sajjan, Rohini. (2016). "Predicting Bankruptcy of Selected Firms by Applying Altman Z Score Model". Journal of Research Granthaalayah, Vol. 4, No. 4:152-158.

[39] Sari, EW Puspita. (2014). "Penggunaan Model Zmijewski, Springate,Altman Z-Score dan Grover Dalam Memprediksi Kepailitan Pada Perusahaan Transportasi Yang Terdaftar Di Bursa Efek Indonesia." Fakultas ekonomi dan Bisnis Universitas Dian Nuswantoro.

[40] Springate, Gordon L.V. (1978). Predicting the Possibility of Failure in a Canadian Firm.Unpu blished Masters Thesis. Simon Fraser University. January 1978.

[41] Sugiyono. (2014). Metode Penelitian Kuantitatif Kualitatif dan R\&D. Alfabeta. Bandung.

[42] Syilviana dan Rachmawati (2016) Analisa Kebangkrutan Dengan Menggunakan Model Altman Z-Score Pada Perusahaan Asuransi Yang Go Public di Bursa Efek Indonesia.

[43] Tri, U. Putra dan Arlin, F.Moch. (2014). Analisis Prediksi Tingkat Kebangkrutan Perusahaan dengan Metode Altman Z-Score dan Springate (Studi Kasus Pada Perusahaan di Bursa Efek Indonesia Pada Tahun 200Tercatat di Bursa Efek Indonesia Pada Tahun 2009-2012 ). Jurnal Studi Manajemen Bisnis (JSMB), Volume 1 No. 2.

[44] Undang-Undang No. 40 tahun 2014 Tentang Perasuransian
[45] Yuliastary, E. Citrawati. dan Wirakusuma, Made G. (2014). “Analisis Financial Distress Dengan Menggunakan Z-Score Altman, Springate,Zmijewski Pada Perusahaan PT Fast Food Indonesia Tbk Yang Terdaftar Di Bursa Efek Indonesia (BEI) Periode Tahun 2008-2012." E-Jurnal Akuntansi Universitas Udayana 6.3(2014):379-389.

[46] Zmijewski, M.E. (1984). Methodological Issues Related tothe Estimation of Financial Distress PredictionModels. Journal of Accounting Research, 22: 59-82.

Parwito: Student of Master Program in Post-Graduate Management from Universitas Mercu Buana Jakarta. He worked as a senior manager of the Sharia Operational Support Devision in BRI Life.

Rosalendro Eddy Nugroho is currently a fulltime senior lecturer in Master Program in Post-Graduate Management from Universitas Mercu Buana Jakarta. He holds a Bachelor of Science degree in Chemichal Engineering from Gadjah Mada University, Master of Management from Universitas Satyagama Jakarta, and $\mathrm{PhD}$ in Management from Bogor Agriculture University. He has taught courses in operation management, supply chain management, enterprise resource planning, and managerial economic. 